\title{
Analisis Sistem Informasi Akuntansi Pengeluaran Kas pada CV Macarindo Berkah Group Jember
}

\author{
Tiara $^{*}$, Fitri Ayu Winarni², Sri Kantun ${ }^{3}$ \\ 1,2,3Universitas Jember, Jember - Indonesia
}

\author{
A R T I C L E I N F O \\ Article history: \\ Received January, 132021 \\ Received in revised form \\ May, 192021 \\ Accepted May, 202021 \\ Available online June, 28 \\ 2021 \\ Kata Kunci: \\ Pengeluaran kas, sistem \\ informasi akuntansi, usaha \\ industri. \\ Keywords: \\ Accounting information \\ systems, cash disbursements, \\ industrial enterprises.
}

\begin{abstract}
A B S T R A K
Penelitian ini bertujuan untuk menganalisis Sistem Informasi Akuntansi (SIA) Pengeluaran Kas CV Macarindo Berkah Group Jember. Pengumpulan data dilakukan dengan metode dokumen dan wawancara. Metode analisis data yang digunakan yaitu deskriptif evaluatif. Hasil penelitian menunjukkan bahwa SIA pengeluaran kas CV Macarindo Berkah Group Jember sudah sesuai dengan standar SIA yang berlaku dengan tingkat kesesuaian sebesar 79\%. Kesesuaian tersebut terdiri dari komponen aktivitas SIA pengeluaran kas, dokumen, catatan akuntansi, fungsi dan bagan alir dokumen. Sehingga dapat disimpulkan bahwa sudah sesuai dengan standar SIA yang berlaku, namun belum maksimal dikarenakan beberapa kekurangan antara lain tidak adanya aktivitas menyetujui faktur pemasok, tidak adanya jurnal pengeluaran dana kas kecil dan tidak adanya fungsi pemegang dana kas. Berdasarkan hasil yang diperoleh, penulis menyampaikan saran kepada CV Macarindo Berkah Group Jember untuk terus menyempurnakan SIA pengeluaran kas dengan mempelajari standar SIA dan merekrut karyawan yang lebih memahami mengenai SIA pengeluaran kas.
\end{abstract}

\section{A B S T R A C T}

This study analyses the Accounting Information System (AIS) of CV Macarindo Berkah Group Jember's Cash Expenditures. Data collection was carried out by document and interview methods. The data analysis method used is descriptive evaluative. The results showed that the AIS cash disbursements of CV Macarindo Berkah Group Jember were by the applicable AIS standards with a suitability level of 79\%. The suitability consists of AIS components of cash disbursements, documents, accounting records, functions, and document flowcharts. So it can be concluded that it follows the applicable AIS standards, but not maximally due to several shortcomings, including the absence of activity to approve supplier invoices, no petty cash disbursement journal, and no cash fund holder function. Based on the results obtained, the authors submit suggestions to CV Macarindo Berkah Group Jember to continue to improve the AIS cash disbursement by studying AIS standards and recruiting employees who better understand the AIS cash disbursements.

\footnotetext{
* Corresponding author.

E-mail : tiara@unej.ac.id (Tiara)
} 


\section{Pendahuluan}

Kegiatan pengeluaran kas tidak dapat dipisahkan dari usaha industri. Hal ini dikarenakan usaha industri dalam menjalankan usahanya membutuhkan kas untuk pengeluaran sehari-hari. Kas adalah segala sesuatu (baik yang berbentuk uang atau bukan) yang dapat tersedia dengan segera dan diterima sebagai alat pelunasan kewajiban pada nilai nominalnya (Soemarsono, 2009). Menurut Rudianto (2012), bahwa suatu perusahaan harus mempunyai kas pada jumlah dan waktu yang tepat agar kas tersebut bisa digunakan secara optimal tanpa mengganggu operasional perusahaan. Persediaan kas harus dikelola sedemikian rupa sehingga tersedia setiap saat dibutuhkan untuk memenuhi kebutuhan dan melakukan aktivitas operasional.

SIA menyediakan informasi akuntansi serta keuangan dan informasi lain yang diperoleh dari proses transaksi akuntansi. Hal tersebut juga diungkapkan Diana \& Setiawati (2011) yang menyatakan SIA adalah sebuah sistem yang mempunyai tujuan pengumpulan data, pemrosesan data yang telah dikumpulkan, serta membuat laporan informasi terkait pada transaksi keuangan perusahaan. Menurut Bodnar \& Hopwood (2006) Sistem informasi akuntansi adalah kumpulan sumber daya seperti manusia dan peralatan yang dirancang untuk mengubah data keuangan dan data lainnya kedalam informasi. SIA merupakan kumpulan elemen berupa formulir, jurnal, buku besar, buku pembantu, serta laporan keuangan yang dipakai manajemen dalam mencapai suatu tujuan perusahaan (Sujarweni, 2015). Jadi, dapat disimpulkan bahwa SIA merupakan sistem yang saling berkaitan yang menyediakan informasi untuk mengelola aktivitas perusahaan yang terdiri atas formulir dan catatan serta laporan keuangan yang telah diolah menjadi suatu informasi yang berguna untuk memudahkan pengambilan keputusan.

Setiap unit usaha tentunya memiliki tujuan yang ingin dicapai dalam penggunaan SIA. Dengan penggunaan SIA diharapkan dapat memberikan hasil yang baik bagi suatu unit usaha tersebut. Tujuan SIA untuk setiap industri kecil bisa saja berbeda, dikarenakan menyesuaikan dengan kebutuhan para penggunanya. Menurut Hall (2009), tujuan dari SIA yakni: (1) Mendukung fungsi penyediaan bagi pihak manajemen. (2) Mendukung dalam mengambil keputusan pihak manajemen. (3) Mendukung operasional harian perusahaan. Krismiaji (2010) menambahkan tujuan pokok SIA yaitu pengumpulan serta pemrosesan data mengenai kegiatan organisasi bisnis dengan cara yang efektif serta efisien, menghasilkan informasi bermanfaat pada pengambilan keputusan, melaksanakan pengawasan yang memadai dalam menjamin data transaksi sudah dicatat serta diproses dengan akurat, dan upaya melindungi data serta aktiva lain yang dipunya oleh perusahaan. Sedangkan Zamzami et al. (2018) berpendapat tujuan SIA yakni untuk mendukung operasi perusahaan sehari-harinya, mendukung keputusan manajemen dalam pengambilan keputusan, mengurangi ketidakpastian, serta untuk memenuhi kewajiban yang berkaitan dengan pertanggungjawaban.

Kegiatan pengeluaran kas suatu usaha industri membutuhkan suatu sistem prosedur pengeluaran kas sebagai bentuk pengendalian internal untuk menghindari kecurangan, penyelewengan, penyimpangan, ancaman ataupun penyalahgunaan anggaran. Hal ini sejalan dengan pendapat Romney \& Steinbart (2016) menyatakan siklus pengeluaran yakni suatu rangkaian aktivitas usaha bisnis serta operasi terkait yang berhubungan terus menerus dalam pembelian suatu produk. Kas sebagai alat pembayaran yang likuid memiliki risiko yang tinggi mudah disalahgunakan karena dapat dicairkan sewaktu-waktu. Pengelolaan pengeluaran kas tersebut dibutuhkan Sistem Informasi Akuntansi (SIA). Adanya penerapan SIA diharapkan aktivitas pengeluaran kas dalam usaha industri dapat berjalan sesuai dengan standar SIA pengeluaran kas.

SIA pengeluaran kas memiliki alur sistematis dalam mencatat seluruh transaksi pengeluaran kas. Prosedur SIA pengeluaran kas harus dilakukan secara runtut mulai dari proses pemesanan bahan baku sampai pengeluaran kas. SIA pengeluaran kas pada usaha industri dalam penelitian ini berfokus pada pengadaan bahan baku. Adanya SIA pengeluaran kas, dapat mengatasi risiko apabila terjadi kerusakan, kehilangan, ataupun penyusutan dalam pembelian bahan baku. Romney \& Steinbart (2016) menyatakan kegiatan SIA pengeluaran kas meliputi proses pemesanan bahan baku, perlengkapan, dan jasa; proses penerimaan bahan baku, perlengkapan, dan jasa; proses menyetujui faktur pemasok; dan proses pengeluaran kas. Setiap proses terdapat pemisahan tanggung jawab dan tugas yang jelas dilakukan pada setiap fungsi yang ada di SIA pengeluaran kas.

Penerapan SIA penting dalam usaha industri, salah satu usaha industri yang menerapkan SIA pengeluaran kas pada kegiatan operasionalnya adalah CV Macarindo Berkah Group Jember. Berdasarkan informasi dari bagian administrasi dan keuangan, sudah terdapat pemisahan bagian berdasarkan tugas dan tanggung jawab pada kegiatan pengeluaran kas. Pengeluaran kas pada CV Macarindo Berkah Group Jember dibedakan menjadi dua yakni pengeluaran di bagian gudang dan pengeluaran di bagian non gudang. Pengeluaran gudang berhubungan dengan pengadaan bahan baku. Sedangkan pengeluaran non gudang meliputi pengeluaran untuk gaji, sewa, listrik, wifi, promosi, sponsorship, dll. CV Macarindo Berkah Group Jember setiap harinya melakukan pengeluaran kas sehingga membutuhkan SIA. Diperlukan kontrol dan 
pengawasan untuk menghindari kecurangan, penyelewengan, penyimpangan, ancaman, ataupun penyalahgunaan anggaran sebagai bentuk pengendalian internal pengeluaran kas pada CV Macarindo Berkah Group Jember.

SIA pengeluaran kas yang baik atau sesuai dengan standar dapat menunjang keberhasilan usaha industri berkaitan dengan pengendalian pengeluaran kas. Besarnya kas harus dijaga sedemikian rupa agar kas selalu sedia dalam jumlah dan waktu yang tepat artinya kas tersedia tidak terlalu besar dan tidak terlalu sedikit. Pengeluaran kas harus dikendalikan sehingga tidak terjadi kecurangan, penyelewengan ataupun penyalahgunaan anggaran, maka diperlukan adanya SIA pengeluaran kas. Indikator penilaian kesesuaian berdasarkan standar SIA pengeluaran kas dengan melihat dari komponen (1) aktivitas pengeluaran kas, (2) dokumen pengeluaran kas, (3) catatan akuntansi pengeluaran kas, (4) fungsi pengeluaran kas dan (5) bagan alir dokumen (Mulyadi, 2016). Menurut Romney \& Steinbart (2016), manfaat yang diperoleh dari SIA yaitu meningkatkan kualitas dan efisiensi biaya produksi atau jasa, peningkatan efisiensi dan efektivitas rantai pasokan, berbagi pengetahuan, meningkatkan struktur pada pengendalian internal dan membantu dalam pengambilan keputusan. Oleh karena itu, diperlukan SIA pengeluaran kas agar kegiatan pengeluaran dapat dilakukan secara baik, dapat dipertanggungjawabkan serta dapat memberikan informasi yang jelas. Sistem serta prosedur akuntansi yang baik dapat membantu usaha industri dalam mencapai tujuan organisasi.

Berdasarkan permasalahan tersebut, peneliti tertarik untuk menganalisis kesesuaian SIA pengeluaran kas yang diterapkan CV Macarindo Berkah Group Jember dengan standar yang berlaku dan mendeskripsikan hambatan dalam menerapkan SIA pengeluaran kas tersebut.

\section{Metode}

Penelitian ini merupakan penelitian deskriptif evaluatif yang bertujuan untuk menganalisis tingkat kesesuaian Sistem Informasi Akuntansi (SIA) pengeluaran kas pada CV Macarindo Berkah Group Jember dan mendeskripsikan hambatan dalam menerapkan SIA pengeluaran kas sesuai dengan standar. Objek penelitian yaitu SIA pengeluaran kas CV Macarindo Berkah Group Jember. Data yang digunakan yaitu data utama berupa dokumen laporan pengeluaran kas CV Macarindo Berkah Group Jember bersumber dari bagian administrasi serta data pendukung yaitu profil CV Macarindo Berkah Group Jember dan hasil wawancara terkait hambatan dalam penerapan SIA pengeluaran kas bersumber dari pemilik CV Macarindo Berkah Group Jember dan bagian administrasi. Metode pengumpulan data dengan (1) wawancara, (2) dokumentasi. Analisis data mengunakan deskriptif evaluatif yaitu dilakukan dengan cara membandingkan data berupa SIA pengeluaran kas pada CV Macarindo Berkah Group Jember dengan standar yang berlaku. Peneliti membuat tabel kesesuaian SIA pengeluaran kas CV Macarindo Berkah Group Jember dengan standar SIA pengeluaran kas untuk menganalisis apakah SIA pengeluaran kas CV Macarindo Berkah Group Jember sudah memadai atau belum (Usman \& Akbar, 2009).

Tabel 1. Penilaian Kesesuaian SIA dengan Standar

\begin{tabular}{|c|c|c|c|c|c|c|}
\hline \multirow{2}{*}{ No } & \multirow{2}{*}{ Indikator } & \multirow{2}{*}{$\begin{array}{c}\text { Standar SIA } \\
\text { Pengeluaran Kas }\end{array}$} & \multirow{2}{*}{$\begin{array}{c}\text { Pengeluaran Kas } \\
\text { CV Macarindo }\end{array}$} & \multicolumn{2}{|c|}{ Kesesuaian } & \multirow{2}{*}{ Ket } \\
\hline & & & & Iya & Tidak & \\
\hline 1. & $\begin{array}{l}\text { Aktivitas } \\
\text { pengeluaran kas }\end{array}$ & & & & & \\
\hline 2. & $\begin{array}{l}\text { Dokumen } \\
\text { pengeluaran kas }\end{array}$ & & & & & \\
\hline 3. & $\begin{array}{l}\text { Catatan akuntansi } \\
\text { pengeluaran kas }\end{array}$ & & & & & \\
\hline 4. & $\begin{array}{l}\text { Fungsi } \\
\text { pengeluaran kas }\end{array}$ & & & & & \\
\hline 5. & $\begin{array}{l}\text { Bagan alir } \\
\text { dokumen }\end{array}$ & & & & & \\
\hline
\end{tabular}

Data hasil tabel penilaian kesesuaian SIA pengeluaran kas dihitung untuk diperoleh persentase kesesuaian, menurut Widoyoko (2012) menggunakan rumus sebagai berikut:

$$
\text { Persentase Kesesuaian }=\frac{\text { Perolehan Skor }}{\text { Skor Maksimal }} \times 100 \%
$$


Tabel 2. Tingkat Kesesuaian SIA Pengeluaran Kas

\begin{tabular}{cc}
\hline Persentase Kesesuaian & Tingkat Kesesuaian \\
\hline $81 \%-100 \%$ & Sangat Sesuai \\
$61 \%-80 \%$ & Sesuai \\
$41 \%-60 \%$ & Kurang Sesuai \\
$21 \%-40 \%$ & Sangat Kurang Sesuai \\
$0 \%-20 \%$ & Tidak Sesuai \\
\hline
\end{tabular}

Sumber: Data diolah, 2020

\section{Hasil dan pembahasan}

Hasil SIA pengeluaran kas yang diterapkan oleh CV Macarindo Berkah Group Jember ditinjau kesesuaian komponennya dengan standar SIA pengeluaran kas diketahui sebagai berikut:

\section{a. Aktivitas Pengeluaran Kas}

Komponen aktivitas SIA pengeluaran kas meliputi (a) aktivitas memesan bahan baku, (b) aktivitas menerima bahan baku, (c) aktivitas menyetujui faktur pemasok, dan (d) aktivitas pengeluaran kas. Aktivitas SIA pengeluaran kas yang terdapat pada CV Macarindo Berkah Group Jember yakni (a) aktivitas memesan bahan baku dengan persentase kesesuaian 100\% dalam kategori sangat sesuai, (b) aktivitas menerima bahan baku dengan persentase kesesuaian 100\% dengan kategori sangat sesuai, dan (c) aktivitas pengeluaran kas dengan persentase kesesuaian 100\% dalam kategori sangat sesuai. Namun, terdapat satu aktivitas yang tidak dilakukan yaitu aktivitas menyetujui faktur pemasok dengan persentase kesesuaian 0\% dalam kategori tidak sesuai .

Ketiadaan fungsi menyetujui faktur pemasok ini dikarenakan adanya saling percaya antara perusahaan dan pihak pemasok. Seperti yang diungkapkan oleh pemilik CV Macarindo Berkah Group Jember sebagai berikut:

"Dari awal usaha macarina dalam pemilihan pemasok tetap setia pada satu pemasok tidak pernah berganti. Sehingga ada komitmen dan rasa saling percaya, pemasok tidak perlu mengirimkan ulang faktur. Saya sudah menganggap seperti saudara. Hal ini karena kita meyakini rasa saling percaya dan yakin keberkahan ada di proses. Perusahaan tetap menjaga proses yang baik antara pabrik, distributor dan agen untuk memperoleh keberkahan dalam usaha. Sehingga seperti sekarang di masa pandemi covid 19 meskipun penjualan tidak seperti kondisi normal tapi tetap cukup. Jumlah produksi juga normal seperti biasa, tidak ada pengurangan jumlah produksi." (Pemilik, 31)

Ketiadaan aktivitas menyetujui faktur pemasok menyebabkan tidak adanya pencocokkan antara pesanan pembelian dan laporan penerimaan barang bahwa perusahaan telah menerima apa yang telah dipesan, faktur tersebut disetujui untuk pembayaran. Romney \& Steinbart (2016) mengatakan sebuah kewajiban hukum untuk membayar pemasok timbul pada saat barang diterima. Karena hal tersebut perusahaan mencataat utang hanya setelah penerimaan dan persetujuan atas faktur pemasok. Ketiadaan aktivitas menyetujui faktur pemasok ini juga menyebabkan tidak adanya peninjauan ulang atas faktur yang dikirim oleh pemasok kepada perusahaan untuk persetujuan pembayaran.

Meskipun CV Macarindo Berkah Group Jember tidak ada aktivitas menyetujui faktur pemasok tidak akan menjadi masalah di samping masih termasuk kategori usaha kecil, perusahaan juga sangat mempercayai pemasok. Namun ada baiknya bila perusahaan yang sudah cukup besar dan mempunyai banyak pemasok diperlukan aktivitas menyetujui faktur pemasok untuk menjaga kredibilitas pencatatan kas perusahaan. Sehingga pada aktivitas menyetujui faktur pemasok pada CV Macarindo Berkah Group Jember dalam kategori tidak sesuai.

\section{b. Dokumen Pengeluaran Kas}

CV Macarindo Berkah Group Jember dalam melakukan pengeluaran kas dilengkapi dengan dokumen transaksi seperti Bukti Kas Keluar (BKK), Permintaan Pengeluaran Kas (PPK), Bukti Pengeluaran Kas (BPK), Permintaan Pengisian Kembali Kas (PPKK). CV Macarindo Berkah Group Jember pada komponen dokumen SIA pengeluaran kas telah menggunakan dokumen SIA pengeluaran kas secara lengkap sehingga pada komponen dokumen sangat sesuai standar dengan persentase kesesuaian $100 \%$. 


\section{c. Catatan Akuntansi Pengeluaran Kas}

Catatan akuntansi yang ada di CV Macarindo Berkah Group Jember yaitu jurnal pengeluaran kas. Namun, terdapat catatan akuntansi yang tidak digunakan yaitu jurnal pengeluaran dana kas kecil. Pada catatan akuntansi persentase kesesuaian sebesar 50\% dalam kategori kurang sesuai

Ketiadaan jurnal pengeluaran dana kas kecil mengakibatkan pengeluaran untuk dana kas kecil dicatat pada jurnal pengeluaran kas. Menurut pemilik CV Macarindo Berkah Group Jember ketiadaan jurnal pengeluaran dana kas kecil menjadikan catatan akuntansi lebih ringkas dan belum dibedakan secara khusus untuk pencatatannya. Menurut Mulyadi (2008), untuk mencatat transaksi pengeluaran dana kas kecil diperlukan jurnal khusus. Jurnal ini sekaligus juga berfungsi sebagai alat distribusi pendebitan yang ada akibat pengeluaran dana kas kecil. Seharusnya, kedua catatan akuntansi tersebut dipisah supaya jelas jurnal pengeluaran kas dan jurnal pengeluaran dana kas kecil.

\section{d. Fungsi Pengeluaran Kas}

Komponen fungsi yang ada di CV Macarindo Berkah Group Jember antara lain fungsi kas dengan persentase kesuaian 75\% dalam kategori sesuai, fungsi akuntansi dengan persentase kesuaian 100\% dalam kategori sangat sesuai dan fungsi pembayaran tunai dengan persentase kesuaian $100 \%$ dalam kategori sangat sesuai. Namun, terdapat 1 fungsi yang tidak digunakan yaitu fungsi pemegang dana kas dengan persentase kesuaian 0\% dalam kategori tidak sesuai.

CV Macarindo Berkah Group Jember tidak menggunakan Fungsi Pemegang Dana Kas. Hal ini menyebabkan perangkapan tugas, yang berpengaruh pada pengendalian kas. Mulyadi (2016) mengatakan, harus memisahkan tanggung jawab secara tegas agar pengendalian internal kas dapat berjalan dengan baik. Seharusnya, kedua fungsi tersebut dipisah sebagai bentuk pengendalian internal dalam mencegah penyelewangan kas. Menurut (Kabuhung, 2013) serta Nuryanti \& Suprantiningrum (2016) pemisahan tugas antar bagian yang krusial akan memperkecil risiko kehilangan dan sebagai bagian dari pengendalian perusahaan. Namun menurut pemilik, antara Fungsi Pemegang Dana Kas dan Fungsi Kas memiliki fungsi yang hampir sama. Hal tersebut diungkapkan oleh pemilik CV Macarindo Berkah Group Jember sebagai berikut:

"Untuk bagian pemegang dana kas disini tidak ada sehingga tugas bagian pemegang dana kas tersebut dirangkap oleh bagian kas. Karena kedua bagian tersebut memiliki fungsi yang hampir sama sehingga bisa lebih efisien dalam perampingan bagian. Hal ini juga mempertimbangkan arus kas yang ada belum terlalu besar yang membutuhkan dana kas dipegang oleh bagian khusus." (Pemilik, 31)

Tugas komponen Fungsi Akuntansi dan Fungsi yang Memerlukan Pembayaran Tunai sudah sesuai dengan standar SIA pengeluaran kas. Sedangkan pada Fungsi Kas, terdapat satu tugas yang tidak dilakukan yaitu menyerahkan cek pada pemegang dana kas saat pembentukan dan pengisian kembali dana kas. Hal ini karena Fungsi Pemegang Dana Kas pada CV Macarindo Berkah Group Jember tidak ada.

Sehingga apabila salah satu fungsi SIA pengeluaran kas tersebut tidak ada, akan mempengaruhi fungsi yang lain. Hal ini dikarenakan SIA harus runtut dan saling terkait satu sama lain. Menurut Laudon \& Laudon (2010) sistem akuntansi secara teknis didefinisikan sebagai suatu rangkaian komponenkomponen saling terkait yang mengumpulkan, memproses, menyimpan serta mendistribusikan informasi guna mendukung pengambilan keputusan serta mengendalikan perusahaan.

\section{e. Bagan Alir Dokumen}

Berdasarkan hasil penelitian pada CV Macarindo Berkah Group Jember belum terdapat bagan alir dokumen SIA pengeluaran kas secara tertulis, namun telah ada aturan standar operasional prosedur mengenai alur pengeluaran kas. Bagan alir menurut Widjajanto (2016) merupakan suatu diagram symbol yang menampilkan aliran data dan rangkaian tahapan operasi dalam suatu sistem. Sehingga peneliti mengambarkan bagan alir dokumen SIA pengeluaran kas sesuai dengan alur yang ada pada CV Macarindo Berkah Group Jember. Komponen bagan alir dokumen SIA Pengeluaran Kas CV Macarindo Berkah Group Jember antara lain 


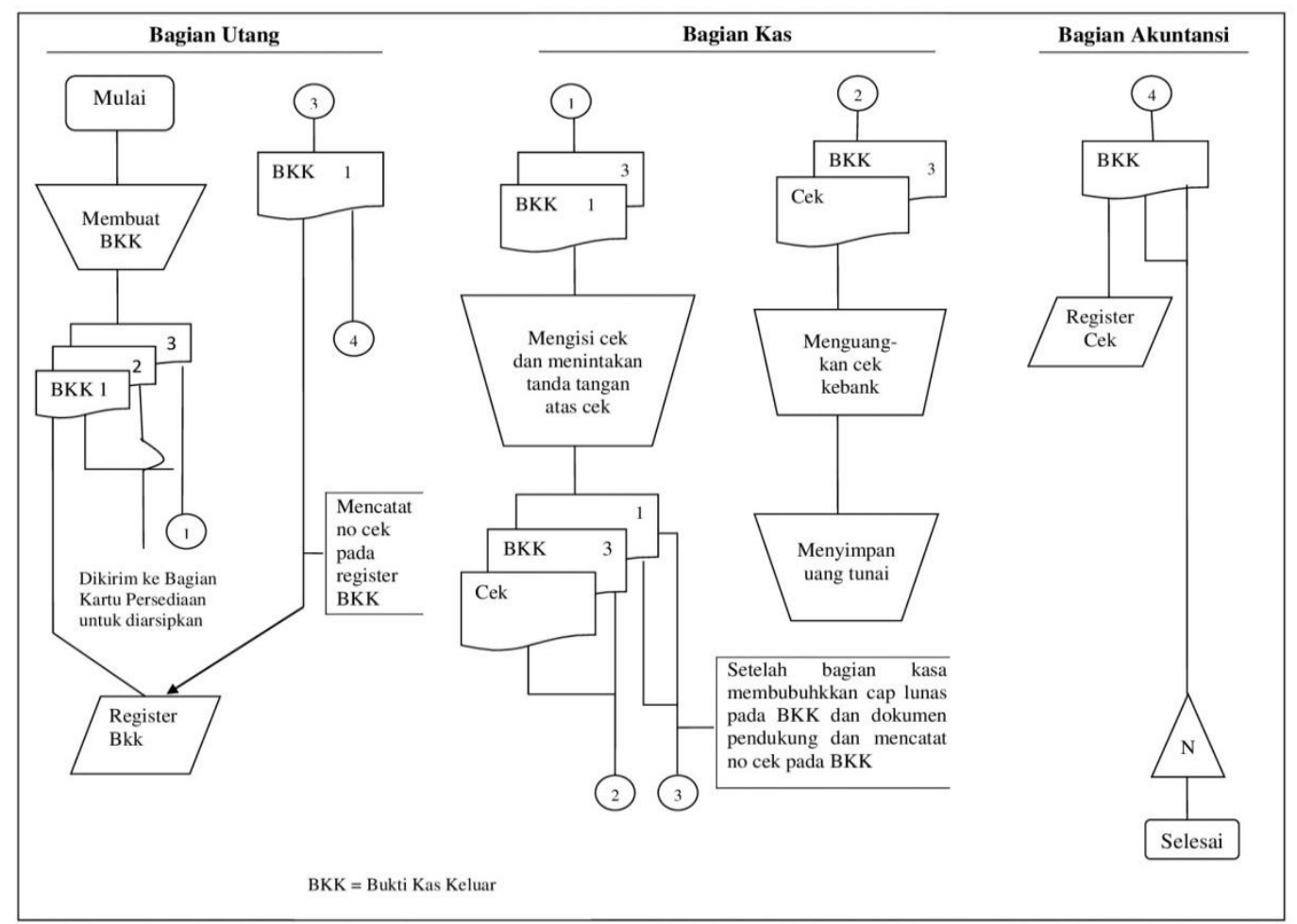

Gambar 1. Bagan alir proses pembentukan dana kas

Bagan alir dokumen pembentukan dana kas dimulai dari Bagian utang membuatkan BKK rangkap tiga. Alir dokumen bagian utang sesuai standar. Namun, dokumen surat keputusan tidak ada, sehingga langsung BKK sebagai surat perintah pengeluaran kas. BKK lembar pertama dimasukkan pada register BKK, setelah BKK lembar pertama diproses. BKK lembar kedua dikirimkan pada bagian kartu persediaan beserta kartu biaya supaya diarsipkan. Sedangkan BKK lembar pertama dan BKK lembar ketiga yang diserahkan pada Bagian Kas. Bagian utang memberikan BKK lembar pertama ke Bagian Akuntansi. Pada Bagian Kas telah sesuai dengan standar. Namun, penyerahan BKK lembar ketiga pada Bagian Pemegang Dana Kas tidak ada. Hal ini dikarenakan pada CV Macarindo Berkah Group Jember tidak ada Bagian Pemegang Dana Kas. Ketiadaan bagian pemegang dana kas menyebabkan terjadinya perangkapan tugas yakni pada Bagian Kas merangkap tugas Bagian Pemegang Dana Kas. Alur pada Bagian Kas diawali diterimanya BKK lembar pertama dan BKK lembar ketiga dari Bagian Utang. Bagian Kas juga mengisi cek dan memintakan otorisasi cek dari CEO CV Macarindo Berkah Group Jember. Setelah dicap lunas BKK lembar pertama diserahkan pada Bagian Utang. Bagian Kas seharusnya menyerahkan cek dan BKK lembar ketiga pada Bagian Pemegang Dana Kas. Namun, karena CV Macarindo Berkah Group Jember tidak ada Bagian Pemegang Dana Kas, maka tugas Bagian Pemegang Dana Kas dirangkap oleh Bagian Kas. Bagian kas juga bertugas untuk mencairkan cek di bank, menyimpan uang tunai dan mengarsip BKK lembar kedua yang seharusnya tugas tersebut dilakukan oleh Bagian Pemegang Dana Kas. Selanjutnya pada Bagian Akuntansi menerima BKK lembar pertama dari Bagian Utang dan mencatat jurnalnya. 


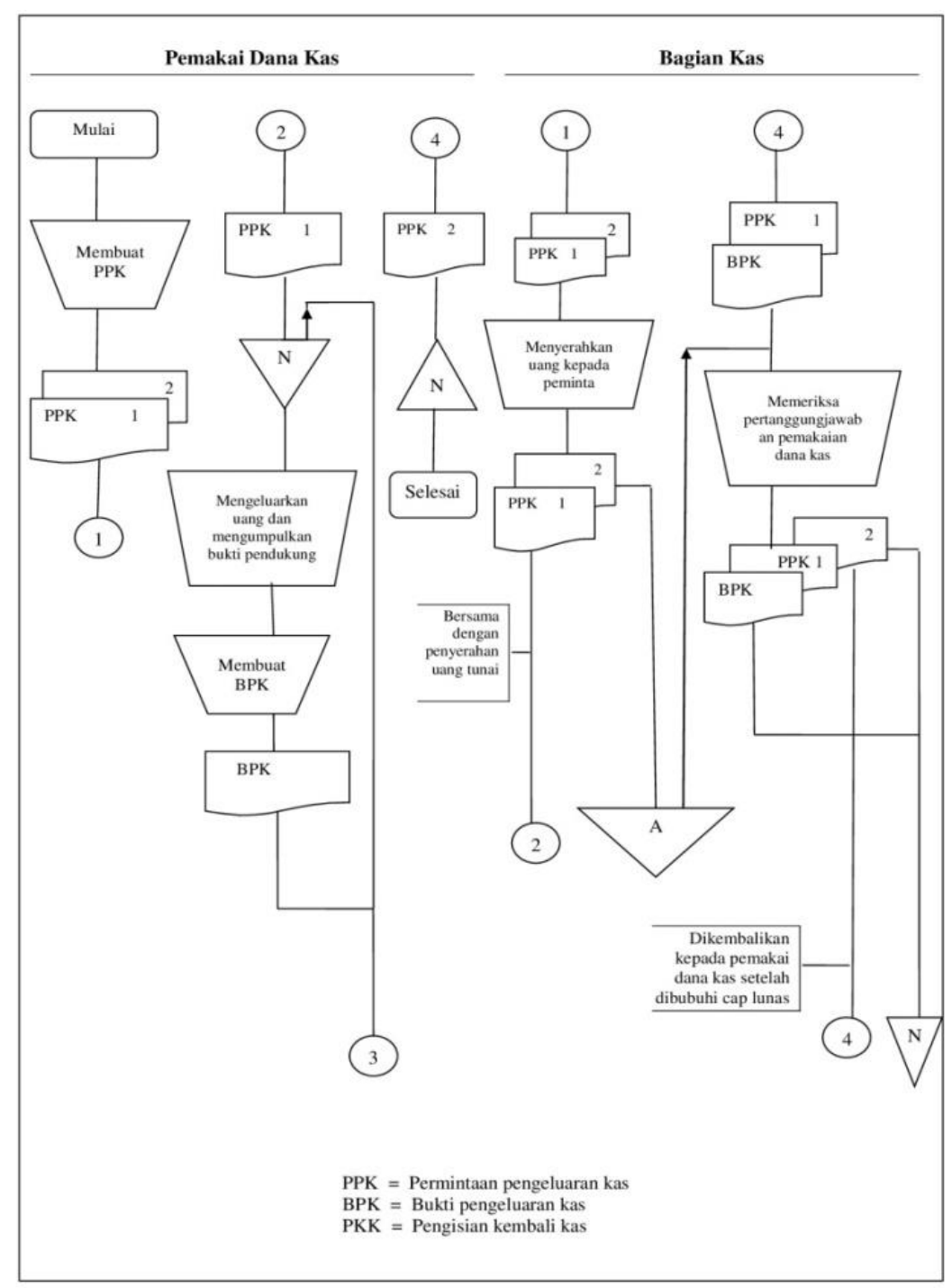

Gambar 2. Bagan alir permintaan dan pertanggungjawaban pengeluaran dana kas.

Bagan alir dokumen permintaan dan pertanggungjawaban pengeluaran dana kas sudah sesuai dengan standar. Namun, Bagian Pemegang Dana Kas pada CV Macarindo Berkah Group Jember tidak ada dan tidak adanya Dokumen Pendukung (DP). Hal ini menyebabkan Bagian Pemegang Dana Kas ini dirangkap oleh Bagian Kas. Sehingga pada bagan alir tidak ada Bagian Pemegang Dana Kas, namun digantikan oleh Bagian Kas. Untuk dokumen hanya ada Bukti Pengeluaran Kas (BPK) dan Permintaan Pengeluaran Kas (PPK) tanpa disertai Dokumen Pendukung (DP). Bagan alir dokumen permintaan dan pertanggungjawaban pengeluaran dana kas dimulai dari Bagian Pemakai Dana Kas membuat Permintaan Pengeluaran Kas (PPK) rangkap dua. PPK lembar pertama dan kedua diberikan pada Bagian Kas. Menyerahkan uang beserta PPK lembar pertama kepada peminta dana kas berdasarkan PPK bagian kas dan PPK lembar kedua diarsipkan berdasarkan abjad. Pemakai Dana Kas mengarsipkan PPK lembar pertama berdasarkan nomor urut. Untuk mengambil uang dan mengumpulkan bukti pendukung, PPK diambil kembali. PPK juga digunakan untuk membuat bukti pengeluaran kas. Bukti Pengeluaran Kas (BPK), dan Permintaan Pengeluaran Kas (PPK) lembar pertama yang digunakan pada kegiatan tersebut diserahkan kepada Bagian Kas. Selanjutnya Bagian Kas mengambil PPK lembar kedua yang telah diarsipkan untuk memeriksa pertanggungjawaban pemakaian dana kas bersama dengan BPK dan PPK lembar pertama yang telah diterima dari Pemakai Dana Kas. Lalu mengarsipkan BPK dan PPK lembar pertama berdasarkan nomor urut. Dokumen diarsip sampai pada saat pengisian kembali kas. Kemudian PPK lembar kedua diberikan pada Pemakai Dana Kas sesudah dibubuhi cap lunas, dan PPK lembar kedua tersebut oleh Pemakai Dana kas disimpan berdasarkan nomor urut. 
Berikut ini merupakan SIA pengeluaran kas yang diterapkan oleh CV Macarindo Berkah Group Jember dan ditinjau kesesuaian komponennya dengan standar SIA pengeluaran kas.

Tabel 3. Perbandingan Kelengkapan Per Komponen SIA Pengeluaran Kas CV Macarindo Berkah Group Jember

\begin{tabular}{|c|c|c|c|}
\hline Komponen & Standar & Realisasi & $\begin{array}{l}\text { Persentase } \\
\text { Kesesuaian }\end{array}$ \\
\hline \multicolumn{4}{|l|}{ Aktivitas Pengeluaran Kas } \\
\hline Aktivitas Memesan Bahan Baku & 4 & 4 & $100 \%$ \\
\hline $\begin{array}{l}\text { Aktivitas Menerima dan Menyimpan } \\
\text { Bahan Baku }\end{array}$ & 5 & 5 & $100 \%$ \\
\hline Aktivitas Menyetujui Faktur Pemasok & 3 & 0 & $0 \%$ \\
\hline Aktivitas Pengeluaran Kas & 3 & 3 & $100 \%$ \\
\hline Dokumen Pengeluaran Kas & 4 & 4 & $100 \%$ \\
\hline Catatan Akuntansi Pengeluaran Kas & 2 & 1 & $50 \%$ \\
\hline \multicolumn{4}{|l|}{ Fungsi Pengeluaran Kas } \\
\hline Fungsi Kas & 4 & 3 & $75 \%$ \\
\hline Fungsi Akuntansi & 6 & 6 & $100 \%$ \\
\hline Fungsi Pemegang Dana Kas & 4 & 0 & $0 \%$ \\
\hline $\begin{array}{l}\text { Fungsi yang Memerlukan Pembayaran } \\
\text { Tunai } \\
\text { Bagan Alir Dokumen }\end{array}$ & 3 & 3 & $100 \%$ \\
\hline $\begin{array}{l}\text { Bagan Alir Dokumen Pembentukan } \\
\text { Dana Kas }\end{array}$ & 11 & 8 & $73 \%$ \\
\hline $\begin{array}{l}\text { Bagan Alir Dokumen Permintaan dan } \\
\text { Pertanggungjawaban Dana Kas }\end{array}$ & 9 & 9 & $100 \%$ \\
\hline Total Skor & 58 & 46 & $79 \%$ \\
\hline
\end{tabular}

Dengan hasil tersebut, maka penerapan SIA pengeluaran kas CV Macarindo Berkah Group Jember dikategorikan "Sesuai". Berdasarkan persentase kesesuaian diperoleh hasil 79\% yang termasuk dalam kategori sesuai. Hasil sesuai tersebut diperoleh dari komponen aktivitas, dokumen, catatan akuntansi dan bagan alir dokumen. Sedangkan ketidaksesuaian sebesar 21\% diperoleh dari ketiadaan Aktivitas Menyetujui Faktur Pemasok, ketiadaan Jurnal Pengeluaran Dana Kas Kecil dan ketiadaan Fungsi Pemegang Dana Kas.

Tabel 4. Hasil Uji t Pengaruh Kompetensi Individu terhadap Kinerja Pegawai

\begin{tabular}{|c|c|c|c|c|c|c|}
\hline & \multirow[b]{2}{*}{ Model } & \multicolumn{2}{|c|}{$\begin{array}{l}\text { Unstandardized } \\
\text { Coefficients }\end{array}$} & \multirow{2}{*}{$\begin{array}{c}\text { Standardized } \\
\text { Coefficients } \\
\text { Beta }\end{array}$} & \multirow[b]{2}{*}{$\mathrm{T}$} & \multirow[b]{2}{*}{ Sig. } \\
\hline & & $\mathrm{B}$ & Std. Error & & & \\
\hline \multirow[t]{2}{*}{1} & (Constant) & 8.039 & 9.529 & & .844 & .403 \\
\hline & Kompetensi Individu & .799 & .079 & .808 & 10.072 & .000 \\
\hline
\end{tabular}

\section{Simpulan dan saran}

Berdasarkan hasil penelitian dan pembahasan dapat disimpulkan bahwa SIA pengeluaran kas CV Macarindo Berkah Group Jember sudah sesuai dengan standar SIA yang berlaku dengan tingkat kesesuaian sebesar 79\%. Hasil tersebut dalam kategori sesuai yang artinya penerapan SIA pengeluaran kas sudah mengikuti aturan-aturan yang ditetapkan dalam pedoman pembuatan SIA. Adapun ketidaksesuaian $21 \%$ meliputi (1) tidak adanya Aktivitas Menyetujui Faktur Pemasok, (2) tidak adanya Jurnal Pengeluaran Dana 
Kas Kecil dan (3) tidak adanya Fungsi Pemegang Dana Kas. Namun ketidaksesuaian tersebut dapat tertutupi dengan aktivitas dan fungsi yang sejenis.

Berdasarkan hasil penelitian yang telah dilakukan, peneliti dapat memberikan saran kepada CV Macarindo Berkah Group Jember terkait SIA Pengeluaran kas, yaitu: (1) CEO CV Macarindo Berkah Group Jember dapat lebih mempelajari mengenai standar SIA pengeluaran kas dan bisa menyesuaikan kembali SIA pengeluaran kas dengan standar SIA pengeluaran kas. (2) Perusahaan merekrut karyawan yang lebih memahami tentang standar SIA pengeluaran kas.

\section{Daftar Rujukan}

Bodnar, G. H., \& Hopwood, W. S. (2006). Sistem informasi akuntansi. In Jakarta: Salemba Empat (Sembilan). Penerbit Andi.

Diana, A., \& Setiawati, L. (2011). Sistem Informasi Akuntansi. CV Andi Offset.

Hall, J. A. (2009). Sistem Informasi Akuntansi (Empat). Salemba Empat.

Kabuhung, M. (2013). Sistem Informasi Akuntasi Penerimaan dan Pengeluaran Keuangan Pada organisasi Nirlaba Keagamaan. Jurnal Riset Ekonomi, Manajemen, Bisnis Dan Akuntansi, 1(3), 339-348.

Krismiaji. (2010). Sistem Informasi Akuntansi (Tiga). Unit Penerbitan dan Percetakan Sekolah Tinggi Ilmu Manajemen YKPN.

Laudon, K. C., \& Laudon, J. P. (2010). Management Information System: Managing the Digital Firm. PrenticeHall.

Mulyadi. (2008). Sistem Akuntansi (Tiga). Salemba Empat.

Mulyadi. (2016). Sistem Akuntansi (Empat). Salemba Empat.

Nuryanti, D., \& Suprantiningrum, R. (2016). Analisis Dan Perancangan Sistem Informasi Akuntansi Penjualan, Piutang Dan Penerimaan Kas (Studi Kasus pada UD.Praktis di Magetan). Jurnal Ilmiah UNTAG Semarang, 5(2), 100-112. http://jurnal.untagsmg.ac.id/index.php/sa/article/view/494

Romney, M. B., \& Steinbart, P. J. (2016). Sistem Informasi Akuntansi (Tiga Belas). Salemba Empat.

Rudianto. (2012). Pengantar Akuntansi. Erlangga.

Soemarsono. (2009). Revisi Akuntansi Suatu Pengantar Buku 1 (Lima). Salemba Empat.

Sujarweni, V. W. (2015). Sistem Akuntansi. Pustaka Baru Press.

Usman, H., \& Akbar, P. S. (2009). Metode Penelitian Sosial. Bumi Aksara.

Widjajanto, N. (2016). Sistem Informasi Akuntansi. Erlangga.

Widoyoko, E. P. S. (2012). Teknik Penyusunan Instrumen Penelitian. Pustaka Pelajar.

Zamzami, F., Nabella, N. D., \& Faiz, I. A. (2018). Sistem Informasi Akuntansi (Tiga). Gajah Mada University Press. 